\title{
Linguistic Diversity in the Urban Linguistic Landscape of Sibiu
}

\author{
Adeline-Alexandra Berdie ${ }^{1, *}$ \\ 1 "Lucian Blaga" University of Sibiu, Romania \\ *Corresponding author. Email: adeline.berdie@ulbsibiu.ro
}

\begin{abstract}
The aim of this paper is to present, categorize and describe the linguistic landscape of Sibiu, by capturing the visible presence of the languages in that area. It examines the use of different languages in the public space of Sibiu, comparing the use of the state language (Romanian) to the use of the minority languages (German and Hungarian). As for the method, over 140 pictures of language signs were analysed, in order to identify the languages used, dividing them into categories according to the discourse type. Special attention will be given to the distinction between official and nonofficial multilingual signs.
\end{abstract}

Keywords: Sibiu, Linguistic landscape, multilingualism, public signs.

\section{INTRODUCTION}

Multilingualism in urban areas is not a special phenomenon. This paper focuses on the phenomenon of multilingualism in a selected area in which more than one language is spoken. The starting point of my research is the density of written form encountered in the (multi-ethnic and multicultural) public urban spaces. This also applies to Sibiu, which is a multiethnic region. This historically significant linguistic landscape is characterised by a linguistic diversity that results from the coexistence of three nationalities (Saxons, Hungarians and Romanians).

The suitable field of research for studying any presence of written form in urban or rural areas, is the Linguistic Landscape, which allows to draw conclusions on the linguistic behaviour in public spaces, being able to uncover socio-political realities. The main interest of the Linguistic Landscape lies in promoting the active and conscious perception of what is represented through language.

Rodrigue Landry and Richard Y. Bourhis define Linguistic Landscape as follows: "The language of public road signs, advertising billboards, street names, place names, commercial shop signs, and public signs on government buildings combines to form the linguistic landscape of a given territory, region, or urban agglomeration." [1, p. 25]
Therefore, Linguistic Landscape represents the presence of written form in public space on one hand and the method devoted to researching this written form on the other hand.

One of the reasons why such a research is worth doing is the fact that there is only one study done in the field of Linguistic Landscape in Sibiu. The article is written by Gerhild Rudolf, entitled "Das Toponym Hermannstadt in der visuellen urbanen Sprachlandschaft. Ein Beitrag zur Linguistic Landscape-Forschung" ("The Toponym Hermannstadt in the Visual Urban Linguistic Landscape. A Contribution to Linguistic Landscape research") and published in the volume "Siebenbürgen als Erfahrungsraum. Studien zur deutschsprachigen Literatur, Presse und Schule", edited by Maria Sass and Doris Sava. The article of Dr. Rudolf focusses on the appearances of the toponym Hermannstadt (meaning Sibiu in German) in the public space of Sibiu. [2]

Similar studies were undertaken for some other Romanian multicultural areas. For example the article of Zsuzsanna Dégi, focused on Miercurea Ciuc, a city in Transylvania inhabited mostly by Hungarian ethnics. [3] Another example would be the essay written by Thomas Schares on the linguistic landscape of Bucharest: "Sprachlandschaft Bukarest - Zacuska City". [4] 
I would like to add my own $\mathrm{PhD}$ thesis, under work, which tries to focus on the linguistic landscape of three symbolic Transylvanian cities: Sibiu, Brașov and Cluj-Napoca. The thesis' title is: Sprachliche Vielfalt in der urbanen Sprachlandschaft Siebenbürgens. Interdisziplinäre Annäherungen und Forschungsperspektiven der Linguistic Landscape (Linguistic diversity in the urban linguistic landscape of Transylvania. Interdisciplinary approaches and research perspectives in the linguistic landscape).

\section{METHODOLOGY}

Researches in the Linguistic Landscape field are mainly based on photography and visual analysis. The collected data is usually categorised according to different criteria such as: discourse type, mono- and/or multilingual street signs.

Due to the enormous amount of visual data available in Sibiu, the research field had to be limited to the historical city centre.

Only the meaningful pictures were selected. The examples help to demonstrate certain phenomena and are representative to the entire data corpus of urban writing in order to draw conclusions from the text material about language communities, language politics and linguistic behaviour.

The corpus of this research comprises a partial inventory of the linguistic landscape of Sibiu's historical centre. As it was already mentioned, the research field is the historical centre of Sibiu, delimited by the walls of the old city-fortress, as well as by Andrei Șaguna and Constituției Street.

The main locations investigated were: the Large Square (Piața Mare), the Small Square (Piața Mică), Huet Square, Bălcescu st., Mitropoliei st., General Magheru st., Gheorghe Lazăr st., Filarmonicii st., Timotei Popovici st., Cetății st., Tipografilor st., Arhivelor st. and Tribunei st.

A total of 140 pictures were taken. The criteria used for categorising the pictures are: the discourse type, top-down/bottom-up origin, monolingual/multilingual, written/online type.

The research questions of this article are: What languages are used in the linguistic landscape of the historical centre of Sibiu? Where do these languages become visible? And the research hypothesis of the article is: The languages used in the linguistic landscape of Sibiu are a gauge for the linguistic reality of this area and they are also an indicator of the existence of an intercultural society.

\section{HISTORICAL AND MULTICULTURAL BACKGROUND OF SIBIU}

\subsection{Sibiu - a symbol of multiculturalism in Romania}

The official language of Romania is Romanian and the most important minority languages are German and Hungarian. A series of rights are being guaranteed to the minority language speakers by the Romanian law. For example, article 6 of the Romanian Constitution says that the state recognises and guarantees for members of a recognised minority the right to maintain, develop and express their ethnic, cultural, linguistic and religious identity without any form of discrimination compared to the other Romanian citizens and article 32 asserts that the members of the minority groups have the right to acquire their mother tongue and to be instructed in that language. [5]

Sibiu is located in the southern part of Transylvania, in the Sibiu Depression, crossed by the Cibin River. This is a city characterised by a heterogeneous, multilingual and multicultural population structure. Transylvania is also known by its German name - Siebenbürgen, seven fortresses. These seven locations were: Sibiu, Brașov, Mediaş, Sighișoara, Sebeș, Rupea and Bistrița and they represented the administrative units of the Transylvanian Saxons, from the twelfth century to the end of the nineteenth century. [6, p. 34] The Romanian translation of Siebenbürgen was Sapte Scaune (Seven Seats), not seven fortresses. Sibiu had the title of Hauptstuhl, meaning the main seat. Such a "seat" represented a union of several towns and villages, subject to the same judiciary centre. Therefore Sibiu was the most important of these cities and it was also the centre of the German Lutheran Church. [7]

The two most important and most visible national minorities in Sibiu are the Germans and the Hungarians. The German name of the city is Hermannstadt (The town of Hermann), while the Hungarian name is Nagyszeben.

\subsection{The main minorities in Romania}

As it was already mentioned before, the two main minorities in Romanian are: the Hungarians and the Germans (known as Transylvanian Saxons).

The Hungarians living in Romania represent the largest ethnic minority in Romania. At the 2011 population census, 1,227,623 ethnic Hungarians were 
registered in Romania, representing $6.1 \%$ of the country's population. In Sibiu there are approximately 10893 Hungarians. [8]

Due to the different history of the German minority groups in Romania, we can't talk about a German minority, but about German minorities. [9] These German minorities came from various regions of the German space and immigrated in different centuries in territories that today are part of Romania. In Sibiu there are two German minorities: the Transylvanian Saxons and the Landler, also known as the Transylvanian Landler. [10; 11] The first German settlers, settled near Sibiu, around 1150-1160. The history of the German minority in today's Romania is closely related to the history of the Hungarian minority. In Sibiu live nowadays approximately 4.244 Germans. [8]

Sibiu - the area of my research represents the centre of the German Transylvanian minority where some of the representative institutions (such as the Lutheran Bishopric and the Regional Transylvanian Saxon Museum) are situated.

\section{CONTENT ANALYSIS}

The content on the signs was categorised into discourse types. The term discourse is understood here as a semiotic aggregate based on Scollon (2003). Under the aspect of the discourse types in the Linguistic Landscape, the communicative intentions of visible linguistic signs are analysed. It is explored what infrastructural, regulatory, commercial or transgressive influence have these on the community that observes them. $[12$, p. 326]

Another way to categorise the signs is to make a distinction between top-down and bottom-up signs. Top-down signs are official signs, placed by the government or similar organisations (e.g. street names, road signs, etc.). Bottom-up signs are non-official signs, placed by autonomous social actors such as private organisations, commercial enterprises or individuals. [13]

In the following the individual discourse types are presented and illustrated with examples from Sibiu.

\subsection{Infrastructural signs}

Infrastructural signs, used for orientation in public space, contain place or street names, names of public institutions, such as schools or town halls. [14, p. 326]

The two examples below are very important touristic locations situated in the very heart of the city. As illustrated the infrastructural signs indicating the names of streets or squares are written exclusively in Romanian.

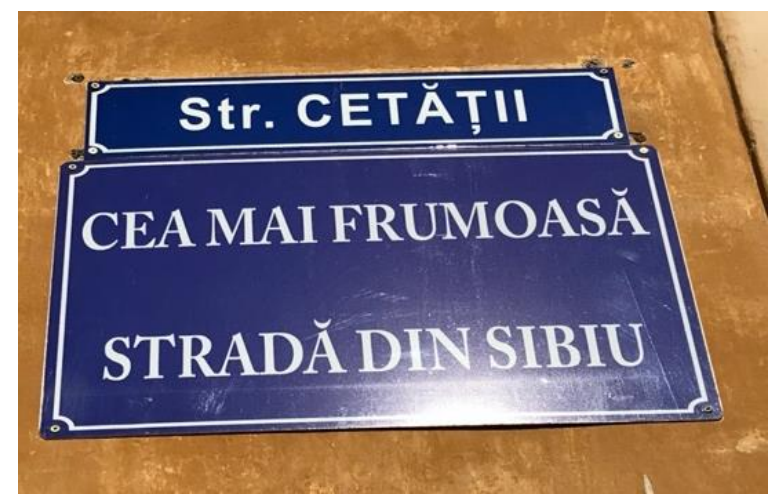

Figures 1 Infrastructural sign (1).

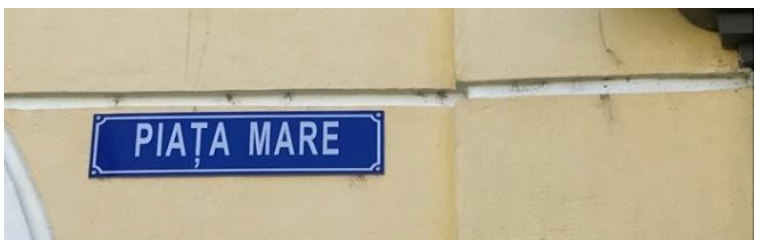

Figures 2 Infrastructural sign (2).

The same situation happens when it comes to infrastructural signs containing valuable road driving indications. We could consider that, even if the text on such driving signs is in Romanian, there are some international universally known symbols that give at least a sense of internationality.

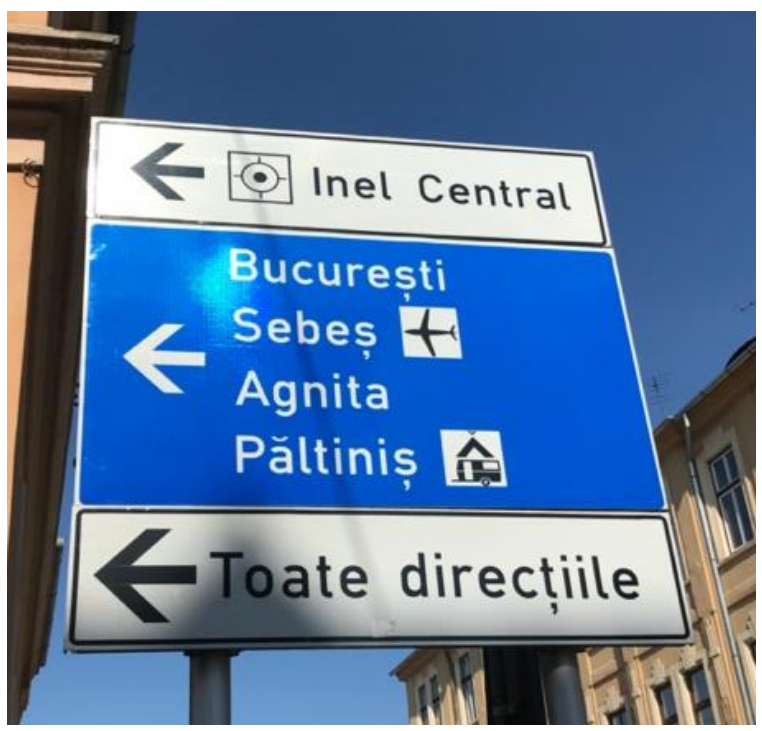

Figure 3 Traffic sign.

These sings, most of them officially regulated in terms of their form and content, are important both for locals and for tourists. The monolingual aspect of these signs is a disappointing aspect. Despite being 
useful for tourists, they should have been a testimony of Sibiu multilinguistic specificity. It was difficult to locate one multilingual touristic sign in this locality.

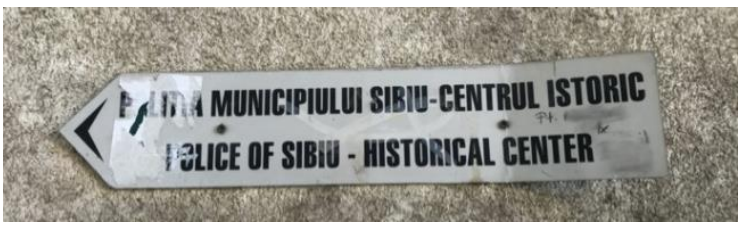

Figure 4 Touristic sign.

\subsection{Regulatory signs}

Regulatory signs illustrate rules for a good coexistence within the community. They provide information on how to behave without being sanctioned. Most of these sings are officially controlled and largely standardised. We noticed once again the same monolingual aspect. [14, p. 327]

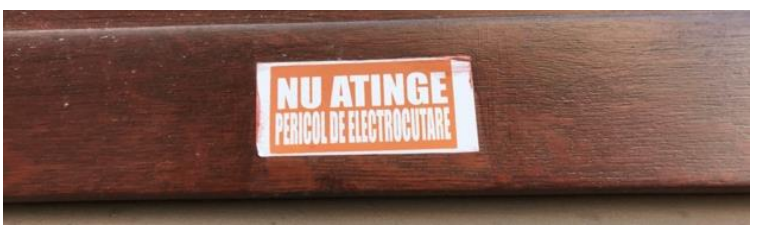

Figure 5 Regulatory sign "Do not touch! Electric shock danger!" written exclusively in Romanian.

The example above underlines the need of a internationalising these signs. The image was taken right near a touristic restaurant in the Small Square. This monolingual sign representing an electric danger could be interpreted as a lack of responsibility at least towards the tourists.

\subsection{Commercial signs}

Commercial signs are the billboards of companies, shops or businesses and provide information about different products or services. These signs also include advertising posters, companies or businesses logos. $[14$, p. 328] Unlike the regulatory and infrastructural signs, the commercial signs do not come from the official local authorities are intended to attract attention of potential clients.

We identified several such signs that revealed a special attention for the foreign tourists and the presence of ethnical minorities as well. Restaurant's Menus in English are meant to attract tourists, but the presence of the German/Hungarian Language when it comes to advertise events organised by representative Institutions belonging to different minorities living in Sibiu is a testimony of the German or the Hungarian presence in the city. The last aspect to be applied included local businesses that are not necessary aimed at tourists. For example a book-shop or a jewellers.

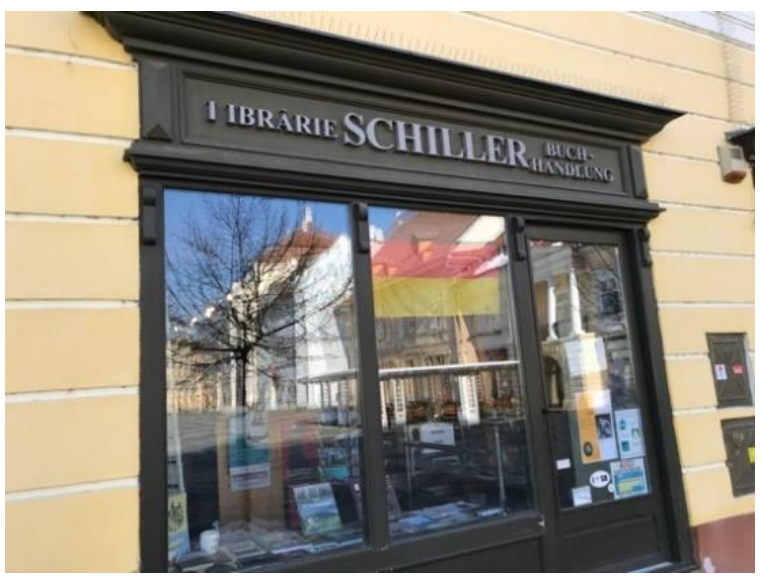

Figure 6 A German book-shop in the Large Square advertised as such.

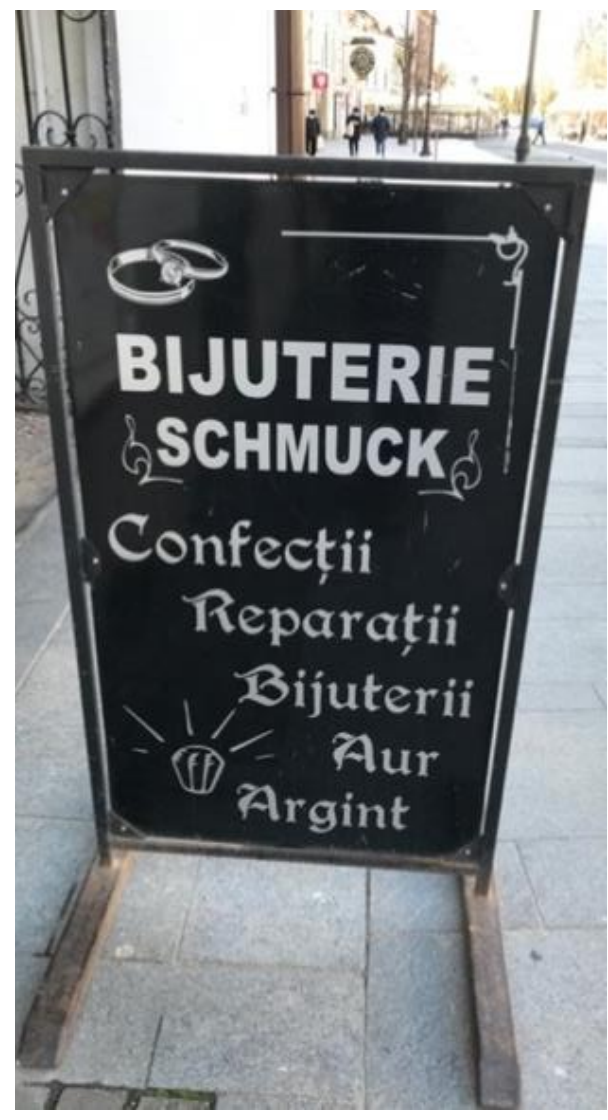

Figure 7 A Jewellery-shop sign with RomanianGerman Inscription on Bălcescu St.

The importance of the multilingualism when speaking about advertising events organised by the minorities' Churches, must be mentioned. These posters tend to give priority to the ethnical languages over the Romanian language. 


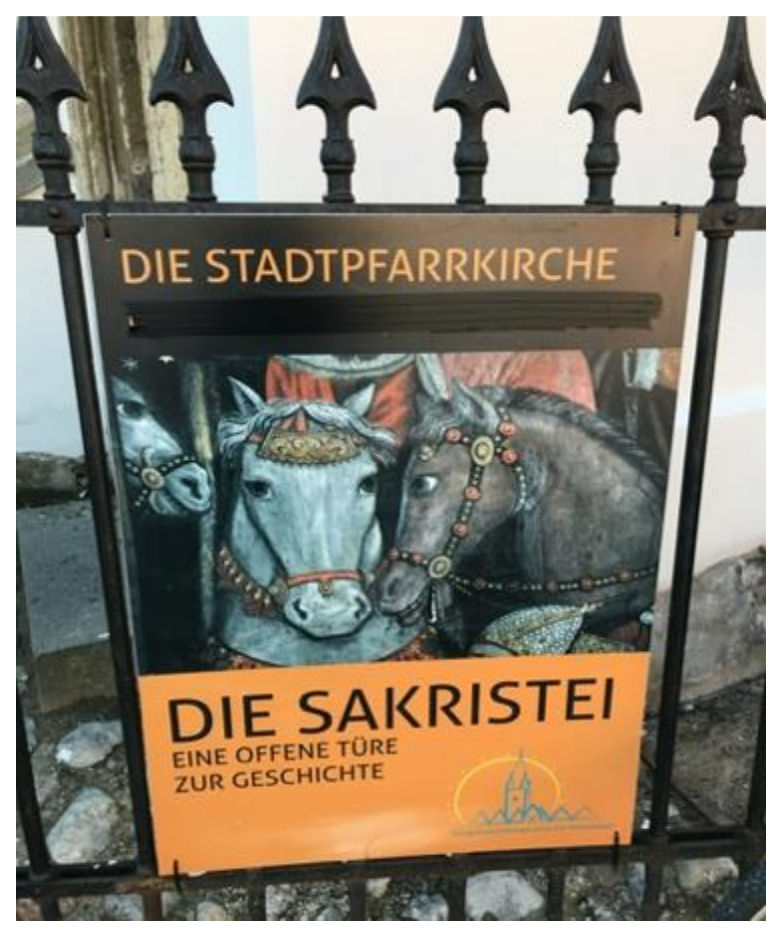

Figure 8 A poster advertising a touristic visit inside the Sacristy of the main Lutheran Church of the city, exclusively in German.

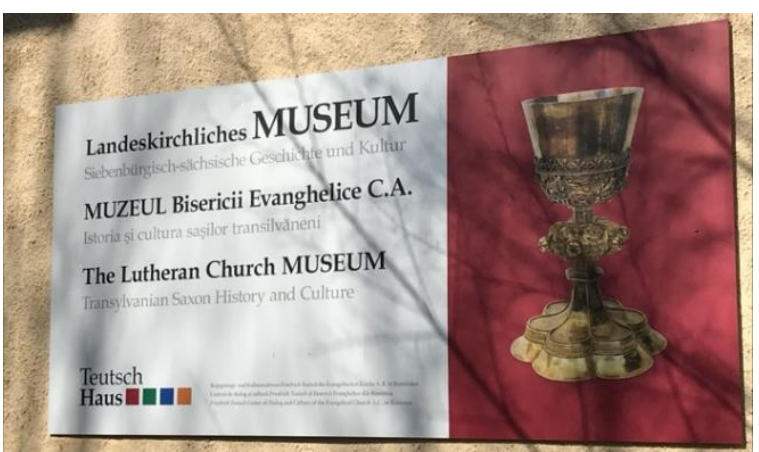

Figure 9 A trilingual poster advertising the Museum of the Lutheran Church. The German language is on the top.

\subsection{Educational and commemorative sings}

In educational establishments, the educational signs usually found are regulatory signs. The educational signs can be produced industrially (by publishers) or individually (by students or teachers). [17] Some examples of educational signs are commemorative tables or posters.

Commemorative signs serve to commemorate important past events or personalities.

Both the educational and the commemorative signs (the older ones) are available in Romanian and German (or even other languages added) or (the newest ones) in Romanian and English.
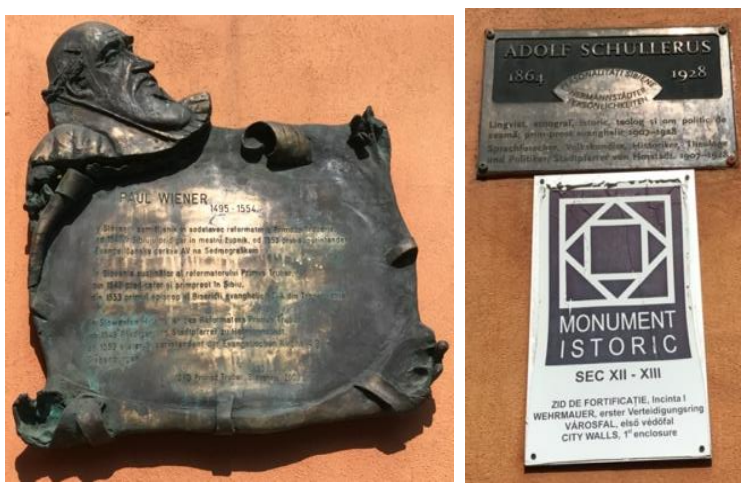

Figure 10 and 11 Examples of multilingual commemorative (bi- or trilingual) plaques or informational plaques (Romanian, German, Hungarian and English).

These plaques emphasise both the Romanian Majority, the German and Hungarian and through the English language they have a touristic purpose as well.

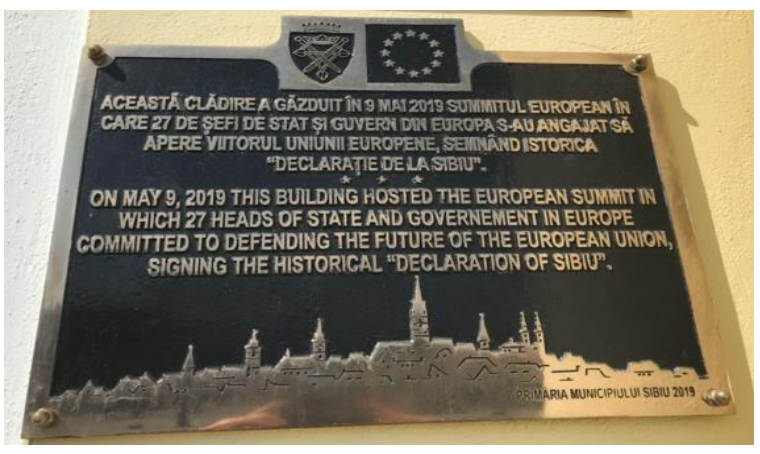

Figure 12 Commemorative plaque for the 2019 European Summit.

\subsection{Transgressive signs}

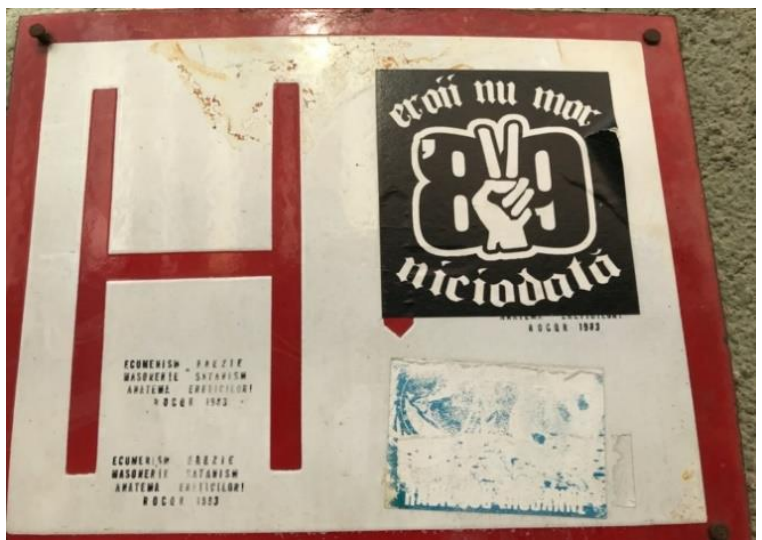

Figure 13 A telling example: an anti-Ecumenism graffiti and sticker reminding the 1988 Revolution heroes and victims. 
The transgressive signs are posted illegally or unauthorized. Good examples in this sense are graffiti or stickers. [17] These stickers are usually monolingual and contain ideological, religious or touristic purpose messages. Most of them are in Romanian or English (for touristic purpose).

\subsection{Online content sings}

The research I performed revealed a new and, though discreet, relevant "written" material form: online content based on $\mathrm{QR}$ codes apps reader. The great advantage of these sings is that they fit in a tiny space, and can offer a lot of written text, being so ecofriendly. The biggest disadvantage is the fact that the QR codes are not always very visible or sometimes accessible to everyone. The QR codes I identified in Sibiu refer to educational or touristic purpose and are multilingual.

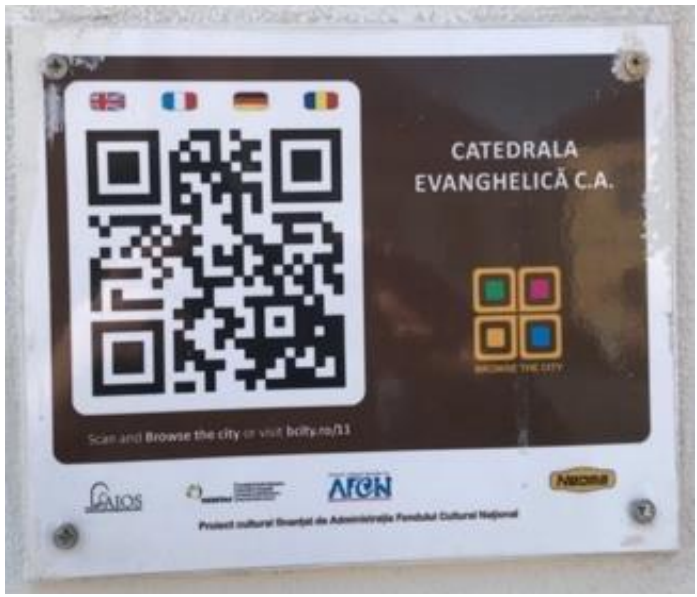

Figure 14 Educational text based on QR codes

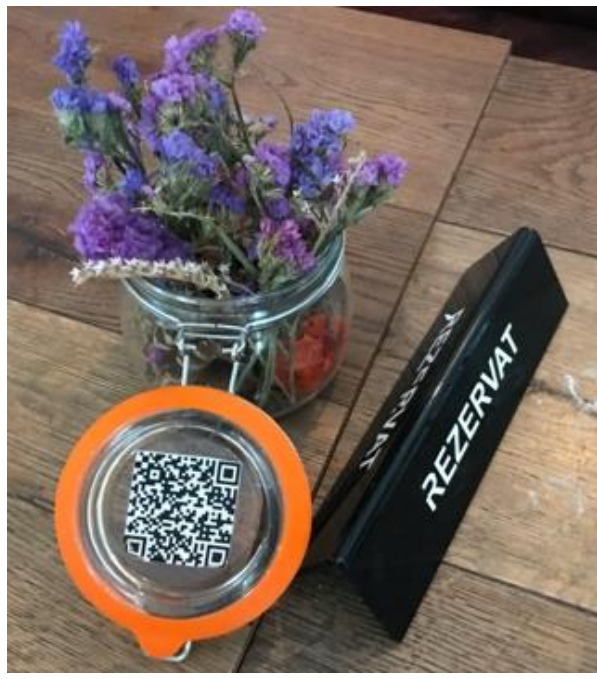

Figure 15 QR code with the Menu in a Restaurant

\subsection{Summarising table}

For a better overview on the linguistic landscape of Sibiu, the information presented previously will be summarised in a table format.

\begin{tabular}{|c|c|c|c|}
\hline Type of signs & Monolingual & Bilingual & Multilingual \\
\hline $\begin{array}{l}\text { Infrastructura } \\
\text { l signs } \\
\text { - street names } \\
\text { - traffic signs } \\
\text { - place names } \\
\text {-names of } \\
\text { schools }\end{array}$ & Romanian & $\begin{array}{l}\text { Romanian + } \\
\text { German) }\end{array}$ & \\
\hline $\begin{array}{l}\text { Regulatory } \\
\text { signs }\end{array}$ & $\mathrm{x}$ & & $\mathrm{x}$ \\
\hline $\begin{array}{l}\text { Commercial } \\
\text { signs }\end{array}$ & $\begin{array}{l}\text { German/ } \\
\text { Hungarian }\end{array}$ & & $\mathrm{x}$ \\
\hline $\begin{array}{l}\text { Educational } \\
\text { and } \\
\text { commemorati- } \\
\text { ve sings }\end{array}$ & & $\mathrm{x}$ & $\mathrm{x}$ \\
\hline $\begin{array}{l}\text { Transgressive } \\
\text { signs }\end{array}$ & $\begin{array}{l}\mathrm{x} \text { (Romanian/ } \\
\text { English) }\end{array}$ & & \\
\hline $\begin{array}{l}\text { Online } \\
\text { content sings }\end{array}$ & & & $\mathrm{x}$ \\
\hline
\end{tabular}

\section{CONCLUSIONS}

Summarising the analysis, it can be said that several languages are visible in the linguistic landscape of the historical city of Sibiu. The most visible ones are: Romanian, English, German and Hungarian. Romanian is the dominant language. It is present on all the signs belonging to the described categories. English is the second most used language. It appears both on bilingual (alongside the Romanian language) and on multilingual signs. It is especially visible on the commercial signs in order to attract tourists and potential clients but it can also be found on the other categories of signs, although not so often. German is the third visible language in the linguistic landscape of Sibiu. It appears on almost every mentioned category but it is more often visible on the commercial signs, alongside Romanian and English. When German appears on mono-linguistic street signs, it usually appears on signs placed on institutions belonging to ethnic minorities. Here we can mention the signs on the churches, which are in most of the cases in the language of the ethnic minority to which they belong. In this case the language is an indicator of the presence of the respective ethnic minority and it does not fulfill a touristic function, as it is the case of the English language.

The German language is also present on the commercial signs of the ethnic minority institutions, 
especially if these institutions intend to advertise an event. This is exactly the case of the Hungarian language, even though the Hungarian appears to be less preeminent than the other above mentioned languages.

On this basis, we conclude that multilingualism is more present on the bottom-up signs, than on the topdown ones.

As a critique to the use of foreign languages in the linguistic landscape of Sibiu, it can be said that there is not enough concern for the multilingualism of such a city, that wants to be considered an important touristic and international city and a symbol of an intercultural society, marked by an intercultural dialogue.

Therefore it can be mentioned that the research questions have been answered, and the research hypothesis has been confirmed. The languages used in the linguistic landscape of the researched city can be truly considered a gauge of the linguistic reality of this place. The multilingualism on the public signs represents a proof of the existence of a multiethnic minority, even if it appears more on signs, belonging to private institutions or on signs placed on the institutions of the ethnic minorities.

The main conclusion that can be drawn is that the linguistic landscape of Sibiu has both an informational and a symbolic function.

Other research perspectives in this field could be for example studies regarding the analysis of announcements from public institutions belonging to minorities, e.g. churches, museums or a research study on the online $\mathrm{QR}$ codes apps reader.

\section{REFERENCES}

[1] R. Landry, R.Y. Bourhis, Linguistic Landscape and Ethnolinguistic Vitality: An Empirical Study, Journal of Language and Social Psychology 16 (1997) 23-49. DOI: https://doi.org/10.1177/0261927X970161002

[2] G. Rudolf, Das Toponym Hermannstadt in der visuellen urbanen Sprachlandschaft. Ein Beitrag zur Linguistic Landscape-Forschung, in: M. Sass, D. Sava (Eds.), Siebenbürgen als Erfahrungsraum. Studien zur deutschsprachigen Literatur, Presse und Schule, Peter Lang, Berlin, 2020, pp. 231-243. DOI: https://doi.org/10.3726/b18025

[3] Z. Dégi, The Linguistic Landscape of Miercurea Ciuc (Csíkszereda), Acta Universitatis
Sapientiae, Philologica 4, 2 (2012) 346-351.

[4] T. Schares, Sprachlandschaft Bukarest - Zacuska City, Deutsch-Rumänische Hefte XVIII, 2 (2015) 12-14.

[5] F. Kuiken, E. van der Linden, Multilingualism, language policy and language education in the Netherlands and Romania: a comparison, Dutch Journal of Applied Linguistics 2 (2013) 205-223 DOI: https://doi.org/10.1075/dujal.2.2.06kui

[6] K. Gündisch, Autonomie de stări și regionalitate în Ardealul medieval, in: Asociaţia de studii Transilvane Heidelberg (Ed.), Transilvania şi saşii ardeleni în istoriografie, Hora Sibiu, Sibiu, 2001, pp. 33-53.

[7] Asociația de studii Transilvane Heidelberg (Ed.), Transilvania şi saşii ardeleni în istoriografie, Hora Sibiu, Sibiu, 2001.

[8] The National Institute of Statistics (Ed.), Recensământul populației și locuințelor, Direcția de Editare a Publicațiilor Statistice, București, 2013.

[9] E. Wagner, Istoria sașilor ardeleni, Meronia, București, 2000, p. 14.

[10] K. Gündisch, Siebenbürgen und die Siebenbürger Sachsen, Langen-Müller, München, 1998.

[11] H. Roth: Kleine Geschichte Siebenbürgens, Böhlau Köln, 2007.

[12] E. Knipf-Komlósi, M. Müller, Deutsche Sprache im öffentilichen Raum einer ungarndeutschen Siedlung, in: H. Philipp, A. Ströbel (eds.), Forschungen zur deutschen Sprache in Mittel-, Ost- und Südosteuropa, vol. 6, Friedrich Pustet, Regensburg, 2018, pp. 319-341.

[13] E. Ben-Rafael, E. Shohamy, M. Amara, N. Trumper-Hecht, Linguistic landscape as symbolic construction of the public space: The case of Israel, in D. Gorter (ed.), Linguistic Landscape: A New Approach to Multilingualism, Multilingual Matters, Clevedon, 2006, pp. 7-30.

[14] E. Knipf-Komlósi, M. Müller, Deutsche Sprache im öffentilichen Raum einer ungarndeutschen Siedlung, 2018. https://edit.elte.hu/xmlui/handle/10831/42633

[17] F. Kuhlee, Schildertypen: Eine Übersicht, https://www.linguasnapp.unihamburg.de/forschung/schildertypen.html 